TERRITORY OF ALASKA

DEPARTMENT OF MINES

$P E-051-01$

MEMORANDUM REPORT

on

A RADIOMETRIC INVESTIGATION OF THE CONAELL PROPERTY, 28 MILE, YUKON RIVER, CIRCLE DISTRICT

to

LEO H. SAARELA

Commissioner of Mines

by

JAMES A. WILLIAMS

Associate Mining Engineer

March 8, 1951 
MEMORANDUM REPORT

on

A RADIOMETRIC INVESTIGATION OF THE CONNELL PROPERTY, 28 MILE, YUKON RIVER, CIRCLE DISTRICT

INTRODUCTION

At the request of Paul A. Conne11, Centra1, Alaska, the writer examined the Connell property at 28 mile on the Yukon River for radioactiv ity and made a brief geological reconnatssance of the surrounding area on JuTy 23 , to $25,1951$.

\section{SUMMARY AND RECOMMENDATIONS}

Results of radiometric readings with an Eltronics radiation detector on the property indicate a moderate possibility of commercial radioactive material at depth, but radioactive samples could not be isolated. Three other weakly radioactive areas exist within an approximate two-and-one-half-mile radius. The probability of finding an economically important concentration of radioactive minerals is not large enough to warrant an expensive method of prospecting.

It is recommended that excavation by hand be continued as Jong as the radioactivity increases with depth. Mechanical excavation is not recommended if a large expense or loss of revenue should be incurred thereby. If mechanical excavating equipment is brought to the property, it is recommended that the excavating be constantly checked as closely as possible and abandoned if results are not encouraging.

\section{LOCATION}

Connell's property is on the north bank of the Vukon River, 28 miles upstream from Circle City. (See Figure 1.) The place is locally known as 28 Mile, and the approximate geographical coordinates are $143^{\circ} 50^{\prime} \mathrm{W}$ Longitude and $65^{\circ} 32^{\prime} \mathrm{N}$ Latitude. The camp is actually situated on the right limit of Hughes Slough about one-half mile upstream from the confluence where the slough re-enters the river. The island formed by the slough and the river is three miles long. The slough extends upstream from connell's in a straight line for approximately a mile and is about 450 feet wide, making a good landing for float planes and ski planes in the proper seasons. 
Figure 2 is a photograph taken from the river showing Conne1]'s property and the nearby terrain. The camp is in the lower center of the picture, and the ridge or "spur" where the radjoactivity was detected is to the right of the camp. The hills in the background rise to 2000 feet or more, and part of the site of the old Hughes telluride discovery is shown in the picture to the far left of the camp where the sliding has been taking piace.

\section{ACKNOWLEDGMENT}

Acknowledgment and appreciation are due Mr. Connell for his unsurpassed hospitality to the writer during his stay at the property.

\section{HISTORY}

In the early 1920's, (reports differ on the date) Albert Hughes found some rich telluride float just downstream from the present conne1l camp. Considerable prospecting was done in the near vicinity, but the bedrock source was never found. Connell has prospected the area for several years, but has been equally unsuccessful in locating the telluride. In the course of his prospecting, however, he has found several areas of weak radioactivity, the most promising being on a sloping ridge quite close to his camp. J. C. Roehm, then Associate Mining Engineer for the Department of Mines, arade an investigation of the area in July 1949 and wrote a summary report thereon to the Commissioner of Mines. Roehm did not have a Geiger counter in his possession at the time of his visit.

\section{GEOLOGY}

Phancon Creek enters Hughes Slough about one mile east of the Connell property. Its right limit is steeply dipping slates and shales without evidence of much movement or distortion. The left limit is also very steep and is covered with vegetation. Considerable slide rock was observed which was stained by many colors, mostly iron oxides, and barite float was much in evidence.

At a fork near the head of Phanton creek, about $11 / 2$ miles from the slough, radioactivity slightly above normal was found. Several checks showed an average of 40 counts per minute, while the background count in the near vicinity was about 30 . 
Sulphur Creek enters Hughes Slough about one mile upstream from Phanton Creek. It contains two beaver lakes. Above the lakes on the right limit is a formation of argillaceous shale containing beds which are generally about six inches thick. Included in the formation are concretions up to two feet in dfameter composed at least partly of concentric layers of barite. Barite veins up to six inches thick run through the formation parallel to the bedding.

Abnomal radioactivity approximately equal to that of Phanton Creek was detected in the area of the above strata.

One-half mile upstream from the beaver lakes, Fault Pup enters Sulphur creek at a sharp angle on the right limit, cutting through the argillaceous shale. At an elevation of about fifty feet above the mouth of Fault Pup, radioactive readings of nearly 50 per minute were encountered, and from 1/4 to 1/2 mile up Fault pup at about 500 feet in elevation, counts of around 47 were recorded. Dark colored barite was noted in this last area and the formation resembled that of the radioactive area on Phanton Creek. The background count of the instrument ramained about 30 . In rone of these locations could radioactive samples be isolated.

An open area at a high elevation between Phanton and Sulphur Creeks was reported by Connel1 to be a deposit of bauxite. (See Figure 2).

Downstream from Conne17's property, 24 Mile Bluff is composed of dark volcanic material which is mostly greenstone. On the bluff's downstream side, it contacts thinbedded limestone. 017 shale is interbedded with the 11mestone, and oil seeps were observed on the beach.

At 26 Mile Creek, there are many thin us-turned beds of chert. Between here and Connell's, at $28 \mathrm{Mile}$, were noted several basic dikes cropping out through the sediments on the beach.

The site of the original telluride prospecting tumnels is about $1 / 4 \mathrm{mile}$ below Connell's, but the tunnel portals have been covered by sliderock from above. 
The principal area under investigation is the small ridge or "sput" 300 feet east of the cabin as shown in Figure 2. The south end of the spur is also pictured in Figure 4. It projects out of the hill (Hughes Mountain) toward the river further than any of the neighboring topography, and the surface of it consists of a decomposed dark shale which is mostly in very sma7] pieces. Another 300 feet to the east, sandstone outcroppings project through the shale.

\section{WORK PERFORMED}

Above overburden on the spur, the background count of the radiation detector was about 30 per minute. When a shallow hole was excavated and the probe lowered into it, the count increased to approximately 40 . As the hole was increased to a depth of two or three feet, counts of up to 50 were obtained, the count increasing as the hole was deepened. This is an indication of material in the range of $0.0 \times \%$ equivalent uranium, probably slightly less than $0.05 \% \mathrm{eU}$, at the point of the highest reaction. Five holes were excavated with identical results. Their locations are shown in Figure 5. Bedrock, or rock in place, was not found in any of the holes, nor could any radjoactive samples be isolated that would produce a promising reaction away from the immediate area. The depth to which the writer could dig in a relatively short time was 7 imited by the fact that the finely-divided shale sloughed in constantly, and in order to dig much deeper, cribbing would have been required or the hole would have had to be widened considerably which would have necessitated moving a large amount of material.

\section{CONCLUSIONS}

Four radioactive areas are indicated, though not necessarily of commercial importance. The most serious detraction in the problem of estimating their possible worth is that efforts thus far to isolate radioactive samples that will produce an abnormal reaction away from the respective areas have been unsuccessful. The most favorable are a is the spur near the cabin where by reason of increasing radiometric activity with depth, it is possible that an underlying formation containing a relatively high percentage of uranium or thorium exists: The probability of finding an economically important concentration of radioactive minerals is not sufficiently large to warrant an expensive method of prospecting. 


\section{RECOMMENDATIONS}

It is recommended that prospecting by excavating by hand be continued as long as the radioactivity continues to increase with depth as indicated by a Geiger counter. It is not recommended that heavy mechanical excavating equipment be brought to the property and employed. If equipment should be used, however, then it is recommended that the excavating be constantiy checked by frequent radiometric readings, and if the radiation ceases to increase before radioactive samples of a relatively high percentage are obtained, the work should be abandoned.

Respectfully submitted,

James A. Williams

Associate Mining Engineer 
$51-$ Chorley

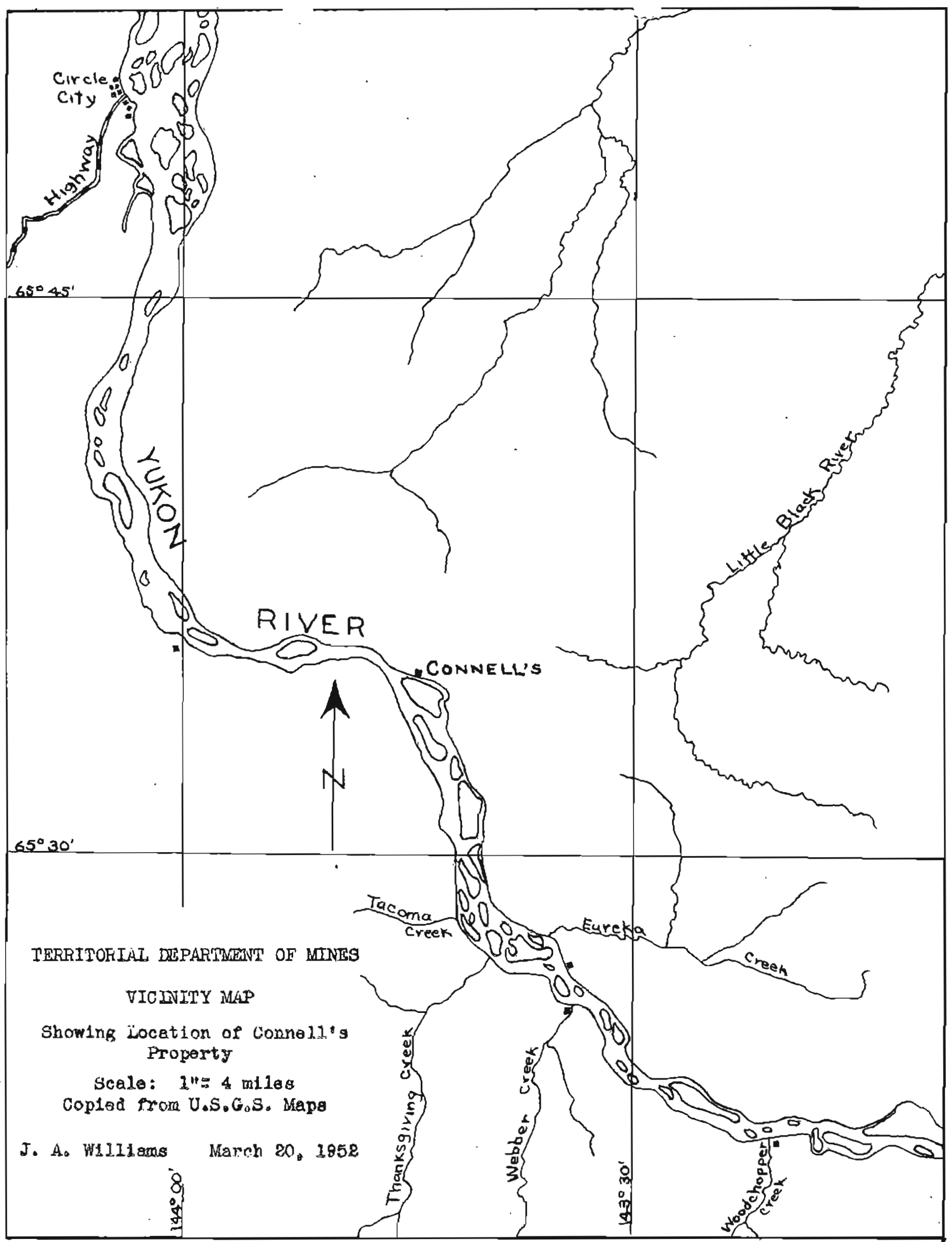



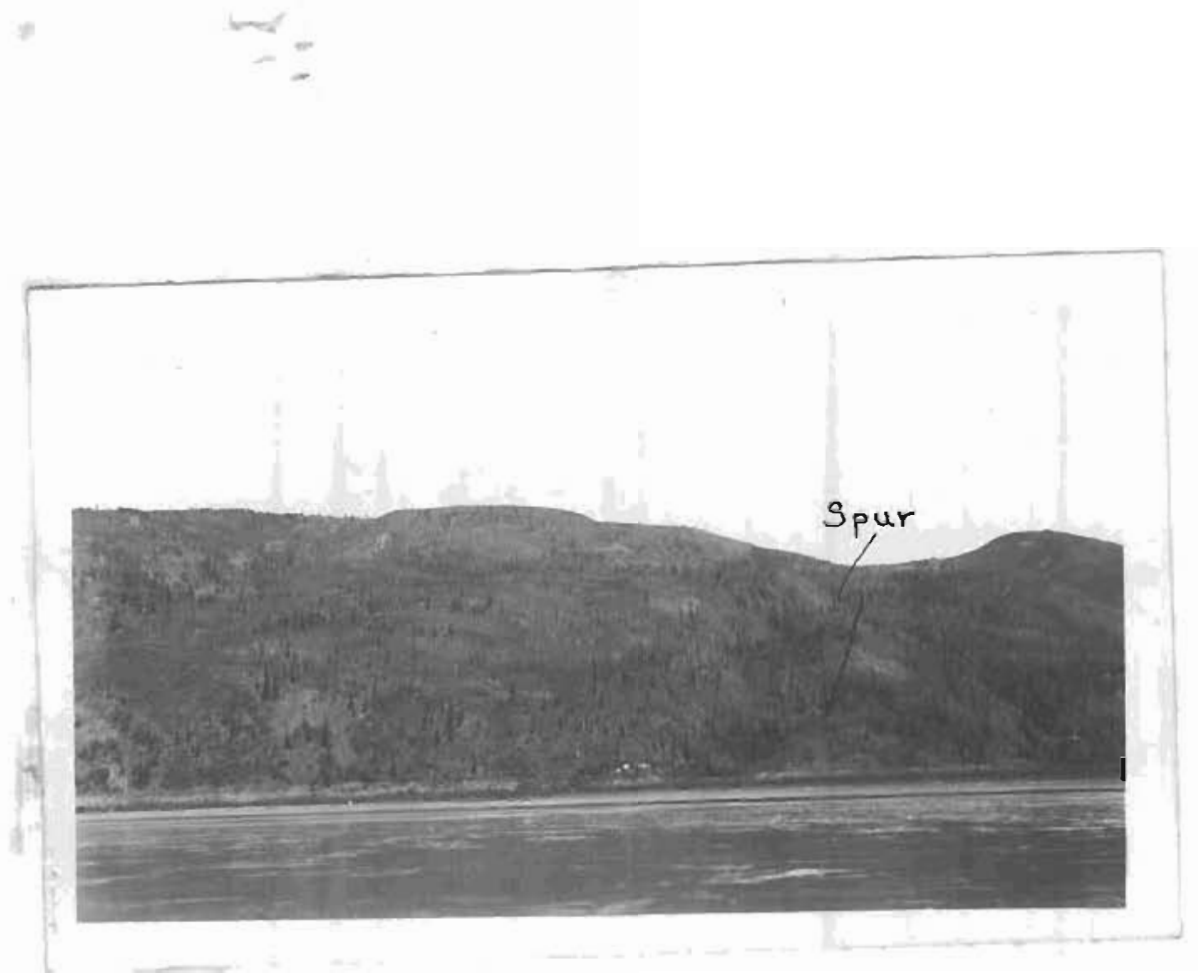

Flgure 2. Connell's Camp and Nearby Terrain.

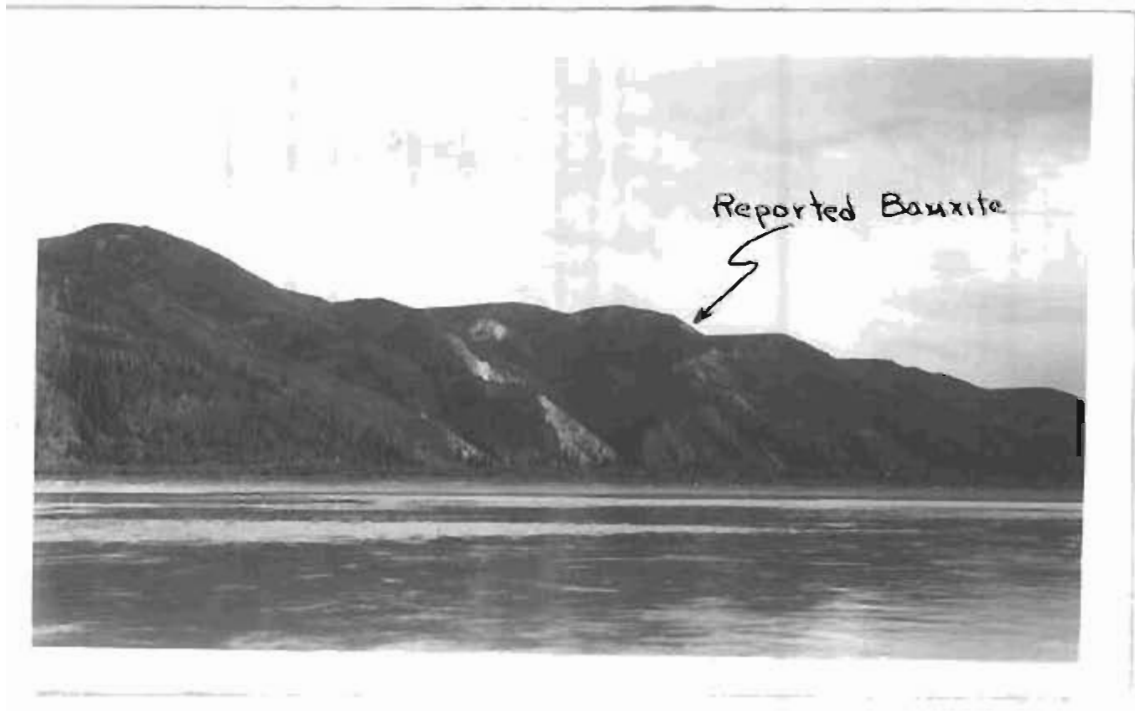

Flgure 3. Area Jpstream from Connell's. 


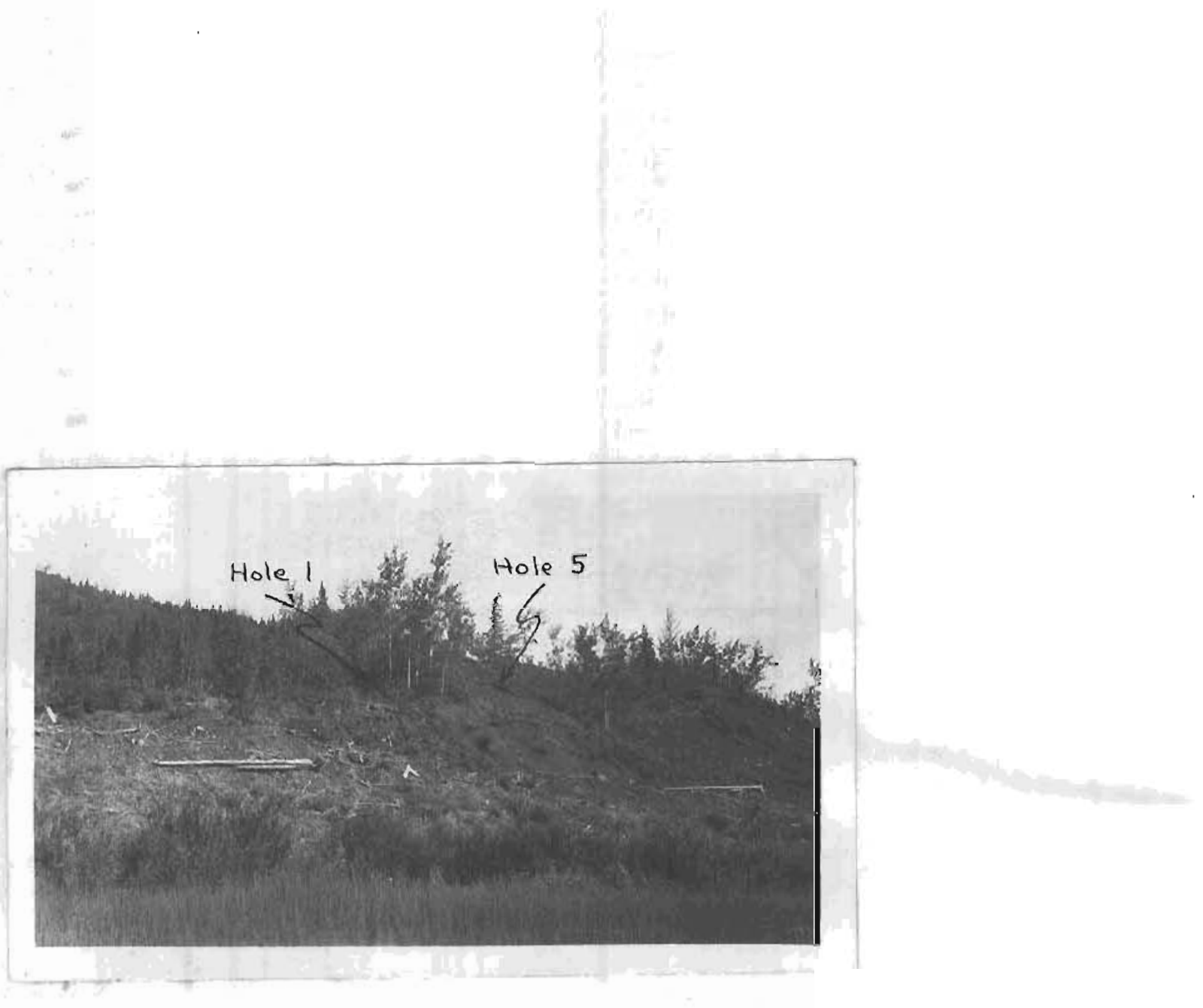

Mgure 4. South End of Spur. 


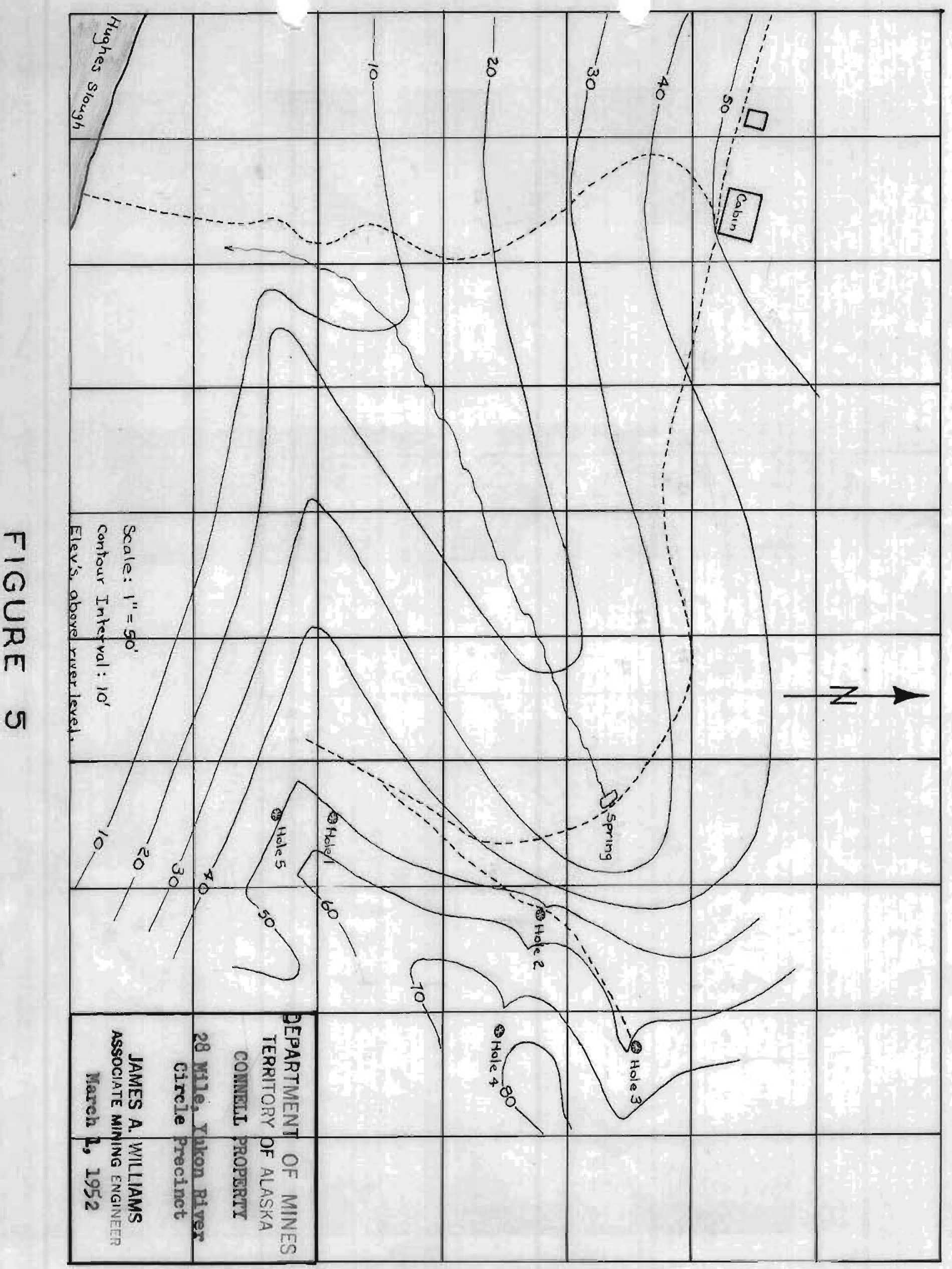

